\title{
Prediction of Prognostic Factors in the Survival of Non-small- cell Lung Cancer Patients with Multiple Brain Metastases
}

\section{Çoklu Beyin Metastazlı Küçük Hücreli Dışı Akciğer Kanserli Hastaların Sağkalımında Prognostik Faktörlerin Öngörülmesi}

\author{
(D) Özlem Mermut ${ }^{1}$, (D) Berrin İnanç ${ }^{1}$, (D) Aytül Hande Yardımc।²
}

1University of Health Sciences Turkey, İstanbul Training and Research Hospital, Clinic of Radiation Oncology, İstanbul, Turkey

${ }^{2}$ Bașakșehir Çam and Sakura City Hospital, Clinic of Radiology, İstanbul, Turkey

\begin{abstract}
Introduction: We aimed to investigate the factors affecting survival in non-small-cell lung cancer (NSCLC) patients with multiple brain metastases.

Methods: One hundred thirty patients who were diagnosed with NSCLC at the time of presentation or during disease followup were evaluated at University of Health Sciences Turkey, İstanbul Training and Research Hospital, Clinic of Radiation Oncology between 2012 and 2017.

Results: In univariate analysis, significant effects of age $>60$ $(p=0.006)$, stage 4 at the time of diagnosis $(p<0.001)$, Karnofsky Performance score (KPS) $<70(p<0.001)$, extracranial metastasis presentation ( $p=0.014)$, uncontrolled primary tumor $(p=0.002)$, headache $(p=0.037)$, and recursive partitioning analysis (RPA) Class III $(p<0.001)$ were observed in predicting early mortality. In multivariate Cox regression analysis, stage 3 at the time of diagnosis [hazard ratio (HR): $0.419,95 \%$ confidence interval (Cl): 0.217-0.809, $p=0.010]$, KPS $\geq 70$ (HR: $14.515,95 \%$ Cl: 5.470 38.519, $\mathrm{p}<0.001)$, and RPA Class I-II (HR: $0.192,95 \% \mathrm{Cl}: 0.102-$ $0.362, p<0.001)$ had a positive effect on overall survival.

Conclusion: Predicting prognostic factors when making whole- brain radiotherapy decisions in NSCLC patients with multiple brain metastases will help in treating such patients appropriately. In multiple brain metastases with NSCLC patients, stage 3 at the time of diagnosis, KPS $\geq 70$, and RPA Class I-II have a positive effect on overall survival.
\end{abstract}

Keywords: Non-small-cell lung cancer, multiple brain metastases, survival

\section{$\ddot{0} Z$}

Amaç: Çoklu beyin metastazı olan küçük hücreli dışı akciğer kanseri hastalarında sağkalımı etkileyen faktörleri araștırmayı amaçladık.

Yöntemler: 2012-2017 yılları arasında Sağlık Bilimleri Üniversitesi, İstanbul Eğitim ve Araştırma Hastanesi, Radyasyon Onkoloji Kliniği'nde, ilk başvuru anında veya hastalığın takibi sırasında beyin metastazı gelișen küçük hücreli dıșı akciğer kanseri tanılı 130 hasta değerlendirildi.

Bulgular: Tek değișkenli analizde, yaș $>60(p=0,006)$, tanı anında evre 4 hastalık $(p<0,001)$, Karnofsky Performans skoru (KPS) $<70(p<0,001)$, ekstrakraniyal metastaz varlığı $(p=0,014)$, primerin kontrol altında olmaması $(p=0,002)$, baş ağrısı $(p=0,037)$ ve RPA sınıfı III $(p<0,001)$ erken mortaliteyi tahmin etmede istatistiksel anlamlı olarak gözlendi. Çok değișkenli Cox regresyon analizinde, ilk başvuru anında evre 3 hastalık (HR: 0,419, 95\% Cl: 0,217-0,809, p=0,010), 70 $\geq$ KPS [hazard ratio (HR): $14,515,95 \% \mathrm{Cl}: 5,470-38,519, p<0,001]$ ve $R P A$ Sinıf I-II'nin (HR: 0,192, 95\% Cl: 0,102-0,362, $\mathrm{p}<0,001)$ genel sağkalım üzerinde olumlu etkisi vardı.

Sonuç: Çoklu beyin metastazı olan küçük hücreli dıșı akciğer kanseri hastalarında tüm beyin radyoterapisi kararı verirken prognostik faktörlerin öngörülmesi hastaların uygun şekilde tedavi edilmesine yardımcı olacaktır. İlk bașvuru anında evre 3 hastalık, KPS $\geq 70$ ve RPA sınıf I-II çoklu beyin metastazı olan küçük hücreli dıșı akciğer kanseri hastalarında genel sağkalımı olumlu yönde etkiler.

Anahtar Kelimeler: Küçük hücreli dıșı akciğer kanseri, çoklu beyin metastazı, sağkalım 


\section{Introduction}

The most commonly known cancers that metastasize to the brain are lung cancer, breast cancer, and melanoma. Lung cancer is the main cause of cancer mortality and a type of malignancy in which brain metastases are often observed (1). For patients with solid tumors, brain metastasis shortens life expectancy. It is related to a lower quality of life and survival (2). Approximately $10 \%$ of patients with non-small-cell lung cancer (NSCLC) will have brain metastasis detected during diagnosis, and $30 \%-50 \%$ will develop brain metastasis $(3,4)$. Early diagnosis is attained with a suitable frequency of neurological imaging during magnetic resonance imaging (MRI) screening and treatment follow-up.

The approach to the treatment of brain metastases may be whole-brain radiotherapy (WBRT), surgery, or stereotactic radiosurgery (SRS) (5). The goal of WBRT is to eliminate unrecognized micrometastases on imaging, increase intracranial control, and reducing the risk of mortality due to neurological causes. Survival in patients with symptomatic brain metastases is lower than in asymptomatic patients, independent of the treatment administered $(6,7)$. The most commonly used method to predict the prognosis of a patient with brain metastasis is recursive partitioning analysis (RPA), which includes information on age, extracranial metastasis status, whether the primary tumor is under control, and the Karnofsky Performance score (KPS) (8).

In this study, we aimed to investigate the factors affecting survival in NSCLC patients with multiple brain metastases.

\section{Methods}

This study was approved by University of Health Sciences Turkey, İstanbul Training and Research Hospital Ethics Committee (approval number: 1858, date: 14.06.2019). Due to the retrospective analyzes of data from medical records, informed consent was waived. One hundred thirty patients who were diagnosed with NSCLC during follow-up were assessed at the Radiation Oncology Clinic between 2012 and 2017. OS was determined by calculating the interval between the diagnosis of brain metastasis and the time of final control or death.

The criteria for exclusion from the study were the following: 1) patients with leptomeningeal metastasis, 2) pre-WBRT SRS (the use of high-dose radiotherapy in a single fraction in the treatment of intracranial lesion application), 3) small-cell lung cancer histology, and 4) single brain metastases.

WBRT was performed using opposing lateral fields; a gantry tilt of $3^{\circ}-5^{\circ}$ was used to avoid divergence into the eyes, and multi-leaf collimation blocks were used to ensure proper coverage of the cribriform plate, temporal lobe, and brainstem while shielding the eyes, nasal cavity, and oral cavity. The inferior border was generally set at C1-2. WBRT was administered using a schedule of $20 \mathrm{~Gy}$ in 5 fractions of $4 \mathrm{~Gy} / \mathrm{fx}$ or 30 Gy in 10 fractions of $3 \mathrm{~Gy} / \mathrm{fx}$, for 5 days a week. WBRT (20 Gy-30 Gy) applied to all patients with three-dimensional conformal radiotherapy or intensity-modulated radiotherapy using $6 \mathrm{MV}$ (megavolts) of photon energy.
When WBRT was complete, we reassessed the patients in the first month and every three months thereafter with contrast MRI. Additionally, local recurrence and distant metastasis follow-up examinations were performed every three months. The intracranial answer was assessed with 1.1 new response evaluation criteria in solid tumors (9).

\section{Statistical Analysis}

The characteristics of the patients in the two groups were compared using the chi-square test for categorical variables and the Mann-Whitney $\mathrm{U}$ test for non-categorical variables. Potential prognostic factors were evaluated using the Kaplan-Meier method (log-rank test) for univariate analysis of the OS and also using a multivariate survival analysis of the Cox regression model. The results were reported as risk ratios hazard ratio (HR) and the corresponding 95\% confidence interval $(\mathrm{Cl})$. Results were considered statistically significant at $p<0.05$. Statistical analyzes were conducted with SPSS (version 22.0; IBM Corp., Armonk, NY, USA).

\section{Results}

The median age of the patients was 60 (range: 25-82) years. Fifteen patients were female, and 115 patients were male. Seventy (54\%) of the patients had adenocarcinoma histology. The most common reference complaint was a headache in 48 (37\%) patients. The most common location of metastases was bilateral hemispheres in 74 (57\%) patients.

In univariate Kaplan-Meier survival analysis, of age $>60 \quad(p=0.006)$, stage 4 at the time of diagnosis $(p<0.001)$, KPS $<70 \quad(p<0.001)$, extracranial metastasis presentation $(p=0.014)$, uncontrolled primary tumor ( $p=0.002)$, headache $(p=0.037)$, and RPA Class III $(p<0.001)$ were observed to predict early mortality (Table 1 ).

In multivariate Cox regression analysis, stage 3 at the time of diagnosis (HR: 0.419; 95\% Cl: 0.217-0.809; $p=0.010$ ), KPS $\geq 70$ (HR: 14.515; 95\% Cl: 5.470-38.519; $\mathrm{p}<0.001$ ), and RPA Class I-II (HR: 0.192; $95 \% \mathrm{Cl}: 0.102-$ $0.362 ; p<0.001$ ) had a positive effect on overall survival (OS) (Table 2).

The median follow-up duration was three months (range: 1-56 months, 95\% Cl: 2.239-3.761). The 1-year OS in RPA Class I was 66\%, in RPA Class II, $12 \%$, and in RPA Class III, none. The median OS was 12, 6, and 2 months for patients with RPA Class I, RPA Class II, and RPA Class III, respectively $(p<0.001)$ (Figure 1).

One-year OS was $58 \%$ in patients with KPS $\geq 70$. In multivariate analysis, KPS $\geq 70$ had a positive effect on OS (Figure 2).

The 1-year OS of patients with stage III at the time of diagnosis was 55\%. Moreover, stage 3 at the time of diagnosis had a positive effect on OS (Figure 3).

\section{Discussion}

The brain is the most common area where hematogenous metastasis occurs in patients with lung cancer. While the mean survival of patients with brain metastasis is frequently less than 6 months, it is well recognized that in some subgroups, the mean survival is longer (10). 
Table 1. Clinical characteristics and results of the univariate analysis (Kaplan-Meier, log-rank test) of OS of patients with multiple brain metastases

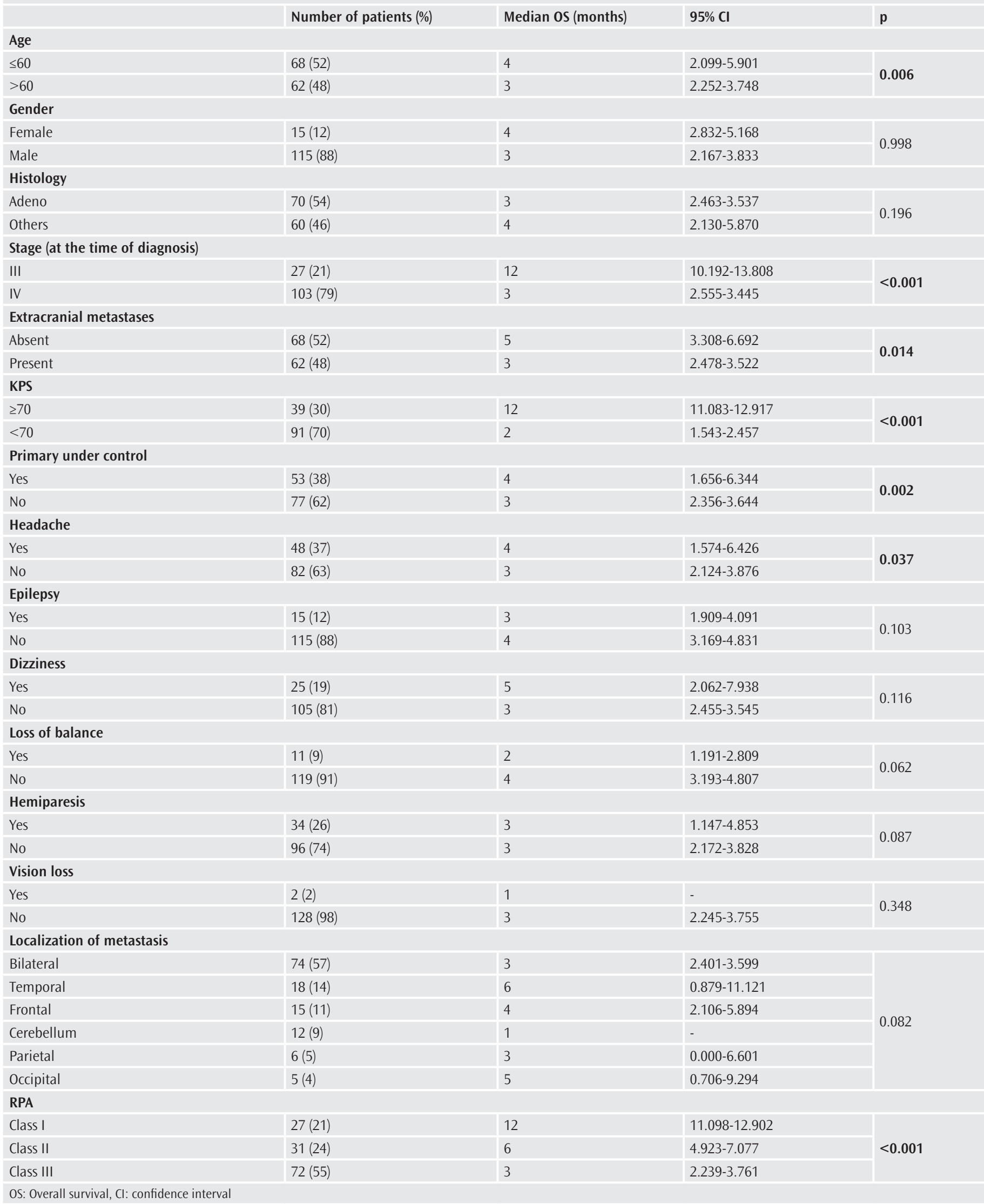


Several studies have shown that patients under 60 years of age are at an increased risk of brain metastasis $(11,12)$. An analysis of 482 patients with stage 3b-4 NSCLC found that, statistically, the risk of brain metastasis was significantly higher in patients less than 60 years of age and in

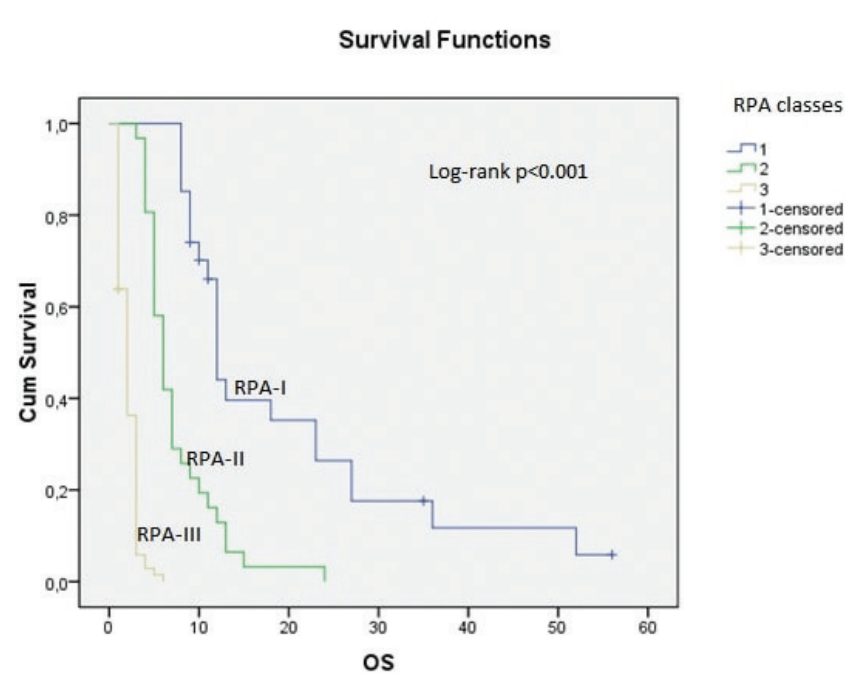

Figure 1. RPA classes

RPA: Recursive partitioning analysis, OS: overall survival

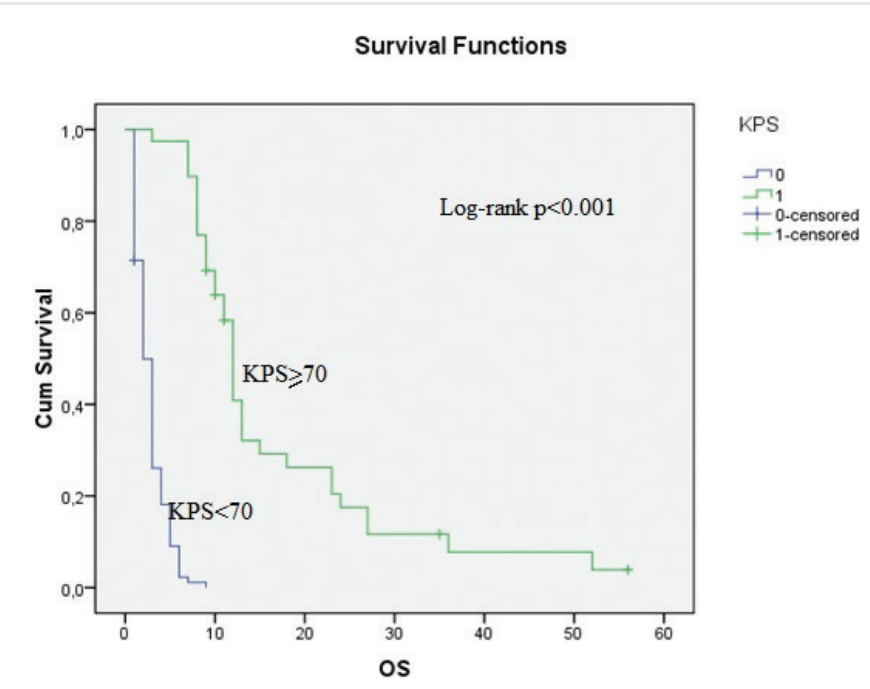

Figure 2. KPS

KPS: Karnofsky Performance score, OS: overall survival patients with adenocarcinoma (13). In another study with 157 patients, age was identified as a prognostic factor (14). Age was determined to be significant in univariate analysis; however, it was not a prognostic factor in the present study.

The prognostic function of gender in brain metastases is unclear. Some studies have demonstrated that, particularly in advanced-stage NSCLC patients, the influence of gender on brain metastases is constrained $(15,16)$. A meta-analysis of risk factors for brain metastases showed that gender could not be used as a marker (17). Nevertheless, some studies show that in early-stage NSCLC patients, the female gender may have predictive value for the incidence of brain metastases $(18,19)$. Gender could have predictive value in early-stage NSCLC but is not appropriate for advanced-stage NSCLC. It has been shown in our study that gender is not a prognostic factor.

We know that lung adenocarcinoma often leads to hematogenous metastasis, whereas epidermoid cell carcinoma often causes lymphatic metastasis (20). The predisposition of NSCLC to brain metastasis is greater in patient subgroups with adenocarcinoma (54.8\%) and undifferentiated carcinoma (31.7\%) than in those with squamous cell carcinoma (21). Again, other studies have also shown that patients with adenocarcinoma and large-cell carcinoma histology have a higher risk of developing brain metastasis compared with squamous cell carcinoma histology $(22,23)$.

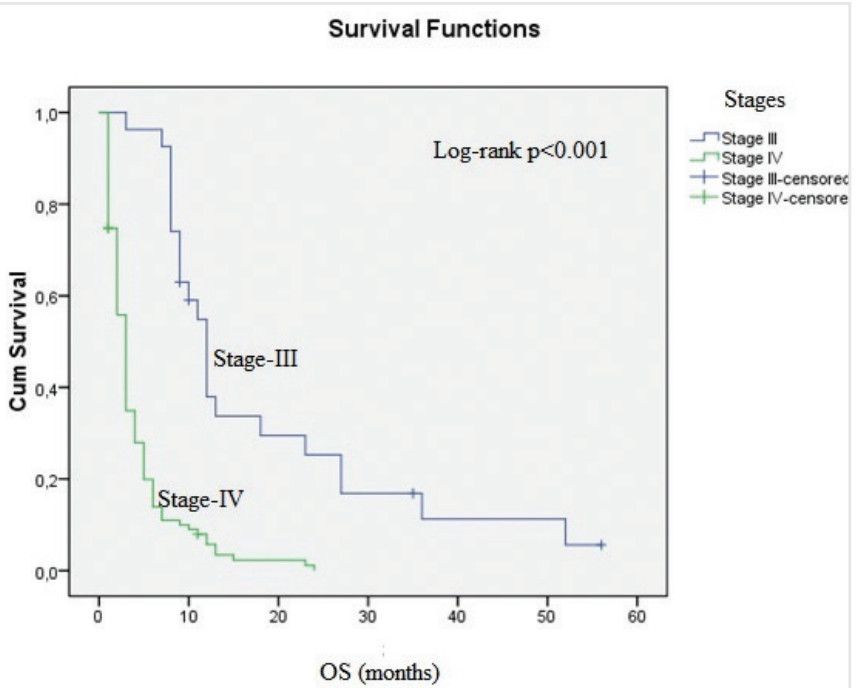

Figure 3. Stages

OS: Overall survival

Table 2. Results of the multivariate Cox regression analysis of OS of patients with multiple brain metastasis

\begin{tabular}{|c|c|c|c|}
\hline & HR & $95 \% \mathrm{Cl}$ & $p$ \\
\hline Age $<60$ vs $\geq 60$ & 1.031 & $0.692-1.536$ & 0.880 \\
\hline Stages 3 vs 4 at the time of diagnosis & 0.419 & $0.217-0.809$ & 0.010 \\
\hline Extracranial metastases absent vs present & 0.759 & $0.521-1.105$ & 0.150 \\
\hline$K P S \geq 70$ vs $<70$ & 14.515 & $5.470-38.519$ & $<0.001$ \\
\hline Primary under controlled vs uncontrolled & 0.875 & $0.583-1.312$ & 0.518 \\
\hline Headache present vs absent & 1.157 & $0.771-1.734$ & 0.481 \\
\hline RPA Class I-II vs III & 0.192 & $0.102-0.362$ & $<0.001$ \\
\hline
\end{tabular}


In the present study, the majority of patients were diagnosed with adenocarcinoma (54\%). We found no statistically significant differences between the histological subtypes. In our retrospective study, ALK, EGFR, and KRAS mutations were not tested in most patients (only $5 \%$ were evaluated). The reason for that at the time of presentation, $79 \%$ of patients were in the metastatic stage and lived a short time.

In two studies, one with patients who developed brain metastasis after surgically resected NSCLC (24) and another with patients who received chemotherapy after cranial radiotherapy (25), the presence of extracranial metastasis was found to be a negative prognostic factor. Another showed extracranial metastasis to be significant in univariate analysis but not significant in multivariate analysis (26). In our study, we found it to be significant in univariate analysis.

In a study which evaluated 1,218 patients, they found that brain metastasis developed as the first site of relapse in patients with NSCLC who underwent curative surgery and had high $\mathrm{pT}$ and $\mathrm{pN}$ stages (27). In another study that evaluated 105 patients, it was shown that as NSCLC progresses, the time until brain metastasis decreases. Delayed growth of brain metastases was associated with a better prognosis but not increased survival (28). The tumor stage at the time of diagnosis was found to be an important factor in OS.

RPA provides a standard for the clinical comparison of brain metastasis patients, and the safety of this standard has been demonstrated by some clinical studies $(29,30)$. Furthermore, in a different study, adenocarcinoma histology and RPA Class I and II (KPS $\geq 70$ ) were related to better OS (31). In our study, RPA Class I-II and KPS $\geq 70$ were also related to better $\mathrm{OS}$.

\section{Study Limitation}

The limitations of this study were that it was performed in a single center, and the majority of patients were not assessed for chemotherapy because chemotherapy could not be administered; therefore, few patients underwent targeted therapy.

\section{Conclusion}

Radiotherapy is one of the basic treatments for brain metastasis. The survival of patients with multiple brain metastases is affected by numerous factors. In our study, stage 3 at the time of diagnosis, KPS 270 , and RPA Class I-II were determined as prognostic factors affecting OS. Predicting prognostic factors when making WBRT decisions in NSCLC patients with multiple brain metastases will help in treating such patients appropriately.

\section{Ethics}

Ethics Committee Approval: This study was approved by University of Health Sciences Turkey, İstanbul Training and Research Hospital Ethics Committee (approval number: 1858, date: 14.06.2019).

Informed Consent: Due to the retrospective analyzes of data from medical records, informed consent was waived.

Peer-review: Externally peer-reviewed.
Authorship Contributions: Surgical and Medical Practices - B.I.; Concept - Ö.M.; Design - B.I., A.H.Y.; Data Collection or Processing - Ö.M., B.I.; Analysis or Interpretation - Ö.M., A.H.Y.; Literature Search - A.H.Y.; Writing - Ö.M.

Conflict of Interest: No conflict of interest was declared by the authors.

Financial Disclosure: The authors declared that this study received no financial support.

\section{References}

1. Bray F, Ferlay J, Soerjomataram I, Siegel RL, Torre LA, Jemal A. Global cancer statistics 2018: GLOBOCAN estimates of incidence and mortality worldwide for 36 cancers in 185 countries. CA Cancer J Clin 2018; 68: 394-424.

2. Goncalves PH, Peterson SL, Vigneau FD, Shore RD, Quarshie WO, Islam K, et al. Risk of brain metastases in patients with nonmetastatic lung cancer: Analysis of the Metropolitan Detroit Surveillance, Epidemiology, and End Results (SEER) data. Cancer 2016; 122: 1921-7.

3. Villarreal-Garza C, de la Mata D, Zavala DG, Macedo-Perez EO, Arrieta O, Aggressive treatment of primary tumor in patients with non-small-cell lung cancer and exclusively brain metastases. Clin Lung Cancer 2013; 14: 6-13.

4. Dempke WC, Edvardsen K, Lu S, Reinmuth N, Reck M, Inoue A. Brain Metastases in NSCLC - are TKIs Changing the Treatment Strategy? Anticancer Res 2015; 35: 5797-806.

5. Abdallah SM, Wong A. Brain metastases in non-small-cell lung cancer: are tyrosine kinase inhibitors and checkpoint inhibitors now viable options? Curr Oncol 2018; 25(Suppl 1): S103-S14.

6. Sahgal A, Soliman H, Larson DA. Whole-brain radiation therapy of brain metastasis. Prog Neurol Surg 2012; 25: 82-95.

7. Tsao MN, Lloyd N, Wong RK, Chow E, Rakovitch E, Laperriere N, et al. Whole brain radiotherapy for the treatment of newly diagnosed multiple brain metastases. Cochrane Database Syst Rev 2012: 2012: CD003869.

8. Gaspar L, Scott C, Rotman M, Asbell S, Phillips T, Wasserman T, et al. Recursive partitioning analysis (RPA) of prognostic factors in three Radiation Therapy Oncology Group (RTOG) brain metastases trials. Int J Radiat Oncol Biol Phys 1997; 37: 745-51.

9. Schwartz LH, Litière S, de Vries E, Ford R, Gwyther S, Mandrekar S, et al. RECIST 1.1-Update and clarification: From the RECIST committee. Eur J Cancer 2016; 62: 132-7.

10. Stelzer KJ. Epidemiology and prognosis of brain metastases. Surg Neurol Int 2013; 4(Suppl 4): S192-202.

11. Dimitropoulos C, Hillas G, Nikolakopoulou S, Kostara I, Sagris K, Vlastos F, et al. Prophylactic cranial irradiation in non-small cell lung cancer patients: who might be the candidates? Cancer Manag Res 2011; 3: 287-94.

12. Ji Z, Bi N, Wang J, Hui Z, Xiao Z, Feng Q, et al. Risk factors for brain metastases in locally advanced non-small cell lung cancer with definitive chest radiation. Int J Radiat Oncol Biol Phys 2014; 89: 330-7.

13. Hsiao SH, Chung CL, Chou YT, Lee HL, Lin SE, Liu HE. Identification of subgroup patients with stage IIIB/IV non-small cell lung cancer at higher risk for brain metastases. Lung Cancer 2013; 82: 319-23.

14. Rades D, Hansen HC, Schild SE, Janssen S. A New Diagnosis-Specific Survival Score for Patients to be Irradiated for Brain Metastases from Non-small Cell Lung Cancer. Lung 2019; 197: 321-6.

15. Bajard A, Westeel V, Dubiez A, Pernet D, Dalphin JC, Depierre A. Multivariate analysis of factors predictive of brain metastases in localised non-small cell lung carcinoma. Lung Cancer 2004; 45: 317-23. 
16. Arrieta O, Saavedra-Perez D, Kuri R, Aviles-Salas A, Martinez L, MendozaPosada D, et al. Brain metastasis development and poor survival associated with carcinoembryonic antigen (CEA) level in advanced non-small cell lung cancer: a prospective analysis. BMC Cancer 2009; 9: 119.

17. Sun DS, Hu LK, Cai Y, Li XM, Ye L, Hou HY, et al. A systematic review of risk factors for brain metastases and value of prophylactic cranial irradiation in non-small cell lung cancer. Asian Pac J Cancer Prev 2014; 15: 1233-9.

18. Ding X, Dai H, Hui Z, Ji W, Liang J, Lv J, et al. Risk factors of brain metastases in completely resected pathological stage IIIA-N2 non-small cell lung cancer. Radiat Oncol 2012; 7: 119.

19. Jacot W, Quantin X, Boher JM, Andre F, Moreau L, Gainet M, et al; Association d'Enseignement et de Recherche des Internes en Oncologie. Brain metastases at the time of presentation of non-small cell lung cancer: a multi-centric AERIO analysis of prognostic factors. Br J Cancer 2001; 84: 903-9.

20. Cai Y, Wang JY, Liu H. Clinical observation of whole brain radiotherapy concomitant with targeted therapy for brain metastasis in non-small cell lung cancer patients with chemotherapy failure. Asian Pac J Cancer Prev 2013; 14: 5699-703.

21. Jin J, Zhou X, Liang X, Huang R, Chu Z, Jiang J, et al. Brain metastases as the first symptom of lung cancer: a clinical study from an Asian medical center. J Cancer Res Clin Oncol 2013; 139: 403-8.

22. Iuchi T, Shingyoji M, Sakaida T, Hatano K, Nagano O, Itakura M, et al. Phase II trial of gefitinib alone without radiation therapy for Japanese patients with brain metastases from EGFR-mutant lung adenocarcinoma. Lung Cancer 2013; 82: 282-7.

23. Shaw MG, Ball DL. Treatment of brain metastases in lung cancer: strategies to avoid/reduce late complications of whole brain radiation therapy. Curr Treat Options Oncol 2013; 14: 553-67.
24. Sakamoto J, Sonobe M, Kobayashi M, Ishikawa M, Kikuchi R, Nakajima D, et al. Prognostic factors for patients in postoperative brain metastases from surgically resected non-small cell lung cancer. Int J Clin Oncol 2014; 19: 50-6.

25. Inal A, Kodaz H, Odabas H, Duran AO, Seker MM, Inanc M, et al. Prognostic factors of patients who received chemotherapy after cranial irradiation for non-small cell lung cancer with brain metastases: A retrospective analysis of multicenter study (Anatolian Society of Medical Oncology). J Cancer Res Ther 2018; 14: 578-82.

26. Yu X, Fan Y. Real-World Data on Prognostic Factors for Overall Survival in EGFR-Mutant Non-Small-Cell Lung Cancer Patients with Brain Metastases. J Cancer 2019; 10: 3486-93.

27. Won YW, Joo J, Yun T, Lee GK, Han JY, Kim HT, et al. A nomogram to predict brain metastasis as the first relapse in curatively resected non-small cell lung cancer patients. Lung Cancer 2015; 88: 201-7.

28. Smith DR, Bian Y, Wu CC, Saraf A, Tai CH, Nanda T, et al. Natural history, clinical course and predictors of interval time from initial diagnosis to development of subsequent NSCLC brain metastases. J Neurooncol 2019; 143: 145-55.

29. Viani GA, da Silva LG, Stefano EJ. Prognostic indexes for brain metastases: which is the most powerful? Int J Radiat Oncol Biol Phys 2012; 83: e325-30.

30. Kondziolka D, Parry PV, Lunsford LD, Kano H, Flickinger JC, Rakfal S, et al. The accuracy of predicting survival in individual patients with cancer. J Neurosurg 2014; 120: 24-30.

31. Harada H, Asakura H, Ogawa H, Mori K, Takahashi T, Nakasu Y, et al. Prognostic factors in patients with brain metastasis from non-small cell lung cancer treated with whole-brain radiotherapy. J Cancer Res Ther 2016; 12: 267-70. 